\title{
KONSUMSI ZAT BESI TERHADAP KADAR HEMOGLOBIN REMAJA PUTRI
}

\author{
Meti Megawati, \& Asep Kuswandi \\ Staf Dosen Poltekkes Kemenkes Tasikmalaya \\ Email: meti.megawati81@gmail.com
}

\begin{abstract}
Abstrak
Tujuan penelitian untuk mengetahui pengaruh konsumsi zat besi terhadap kadar hemoglobin pada remaja putri di MA Athoriyah Kecamatan Cikatomas Kabupaten Tasikmalaya tahun 2017. Penelitian menggunakan quasi eksperimen (pra-eksperimen) one-group pre-post test design. Populasi adalah seluruh remaja putri di MA Athoriyah Cikatomas kelas XII. Sampel didapatkan 50 orang, diambil dengan teknik total sampling. Data diuji menggunakan analisis uji T-dependen, serta regresi linier ganda. Hasil penelitian dari 50 orang responden sebelum diberikan tablet $\mathrm{Fe}$, terjadi anemia sebanyak 26 orang (52\%), dan setelahnya 15 orang (35\%). Hasil uji statistik didapatkan $p=0,000$, dapat disimpulkan ada perbedaan yang signikan antara kadar $\mathrm{Hb}$ sebelum dan sesudah pemberian tablet $\mathrm{Fe}$. Hasil analisis bivariat didapatkan variabel pola makan $(p=0,837)$, pola menstruasi $(p=0,569)$, status gizi $(p=0,358)$, dan pengetahuan $(p=0,166)$. Diharapkan bagi bidang promosi kesehatan dan gizi pada Puskesmas Wilayah Binaan Kecamatan Cikatomas berkoordinasi menindaklanjuti kegiatan pemberian tablet Fe di Sekolah-sekolah.
\end{abstract}

Kata Kunci: Anemia, Konsumsi Zat Besi pada Remaja Putri.

\begin{abstract}
The purpose of the study was to determine the effect of iron consumption on hemoglobin levels in young women at MA Athoriyah Cikatomas District, Tasikmalaya District in 2017. The study used a quasi-experimental (pre-experiment) one-group pre-post test design. The population was all young women at MA Athoriyah Cikatomas class XII. Samples obtained 50 people, taken with the total sampling technique. Data were tested using analysis with the $T$ dependent test, and multiple linear regression. The results of the study of 50 respondents before being given Fe tablets, there were 26 people with anemia (52\%), and after 15 people (35\%). Statistical test results obtained $p=0,000$, it can be concluded that there are significant differences between $\mathrm{Hb}$ levels before and after administration of Fe tablets. The results of bivariate analysis showed dietary variables $(p=0.837)$, menstrual patterns $(p=0.569)$, nutritional status $(p=0.358)$, and knowledge $(p=0.166)$. It is expected that in the field of health and nutrition promotion in the Fostered Community Health Centers in Cikatomas Subdistrict, coordination will follow up on the activities of giving Fe tablets in schools.
\end{abstract}

Keywords: Anemia, Consumption of Iron in Young Women.

\section{PENDAHULUAN}

Anemia merupakan keadaan menurunnya kadar hemoglobin, hematokrit, dan jumlah sel darah merah di bawah nilai normal yang dipatok untuk perorangan. Batasan hemoglobin untuk menentukan seseorang terkena anemia gizi besi atau tidak sangat dipengaruhi oleh umur. Menurut WHO (2000) bahwa kadar Hb pada anak 5-11 tahun kurang dari $11,5 \mathrm{gr} / \mathrm{dl}$, anak 12-14 tahun kurang dari $<120 \mathrm{gr} / \mathrm{dl}$, Wanita tidak hamil kurang dari $12 \mathrm{gr} / \mathrm{dl}$, dan ibu hamil kurang dari $11 \mathrm{gr} / \mathrm{dl}$ (Arisman, 2009).

$$
\text { Data Riskesdas tahun } 2013
$$

menyebutkan bahwa prevalensi anemia pada ibu hamil 37,1\%. Hal tersebut merupakan dampak lanjut dari tingginya prevalensi anemia pada remaja putri yaitu 
sekitar $25 \%$ dan pada wanita usia subur sebesar $17 \%$. Keadaan ini merupakan akibat dari asupan zat gizi besi dari makanan yang dikonsumsi, baru memenuhi sekitar $40 \%$ dari kecukupan (Puslitbang Gizi Bogor, 2007).

Hasil Penelitian Dewi Permaesih (2005) diperoleh prevalensi anemia pada remaja laki-laki sebesar $21 \%$ sedangkan remaja perempuan sebesar $30 \%$. Remaja yang memenuhi kecukupan energi $>70 \%$ sebanyak 38 responden, mereka merupakan kelompok yang lebih berisiko mendapatkan anemia.

Remaja putri dan calon pengantin harus membiasakan mengkonsumsi aneka ragam makanan untuk memenuhi kebutuhan energi, protein dan zat mikro (vitamin dan mineral) karena digunakan untuk pertumbuhan yang cepat, peningkatan volume darah dan peningkatan haemoglobin. Zat mikro penting yang dibutuhkan pada remaja putri adalah zat besi dan asam folat. Kebutuhan zat besi bagi remaja putri dan calon pengantin diperlukan untuk membentuk haemoglobin yang mengalami peningkatan dan mencegah anemia yang disebabkan karena kehilangan zat besi selama menstruasi (Kemenkes, 2014).

Melihat dampak anemia yang sangat besar dalam menurunkan kualitas sumber daya manusia, maka sebaiknya penanggulangan anemia perlu dilakukan sejak dini, sebelum remaja putri menjadi ibu hamil, agar kondisi fisik remaja putri tersebut telah siap menjadi ibu yang sehat.

Strategi untuk mengatasi masalah anemia pada remaja putri adalah dengan perbaikan kebiasaan makan, fortifikasi makanan dan pemberian konsumsi $\mathrm{Fe}$. Mengubah pola makan dan fortifikasi makanan merupakan strategi jangka panjang yang penting tetapi tidak dapat diharapkan dapat berhasil dengan cepat. Cara lainnya adalah dengan konsumsi tablet tambah darah (TTD).

Konsumsi Fe merupakan cara efisien karena mudah didapat, efeknya cepat terlihat, dan harganya relative murah sehingga terjangkau oleh masyarakat luas. Brabin merekomendasikan program pencegahan anemia dengan konsumsi $\mathrm{Fe}$ lebih banyak ditargetkan kepada remaja putri dari pada anak-anak, wanita dewasa atau ibu hamil, karena pemberian suplemen Fe kepada remaja putri akan memberi dampak yang lebih besar pada kesehatan reproduksi dan keberhasilan proses reproduksi dibandingkan sdengan konsumsi selama masa hamil saja. Pemberian TTD bertujuan untuk memutus mata rantai terjadinya stunting, mencegah anemia dan meningkatkan cadangan zat besi dalam tubuh sebagai bekal dalam mempersiapkan generasi yang sehat berkualitas dan produktif.

Berbagai studi intervensi menunjukkan dosis, frekuensi pemberian dan lama pemberian TTD berbeda-beda. WHO/UNICEF dalam Gross et.al menyebutkan dua kali per hari untuk waktu dua sampai tiga bulan. Menindaklanjuti Surat Edaran dari Kementerian Kesehatan Republik Indonesia Direktorat Jenderal Kesehatan Masyarakat Nomor HK.03.03/V/0595/2016, tanggal 20 Juni 2016, tentang Pemberian Tablet Tambah Darah (TTD) pada Remaja Putri dan Wanita Usia Subur. Maka aturan pemberian TTD yang baru adalah pada remaja putri usia 1218 tahun diberikan sebanyak 1 tablet per minggu dengan jangka waktu pemberian sepanjang tahun sehingga kebutuhan TTD per Rematri sekitar 60 tablet/tahun.

Penelitian konsumsi zat besi pada remaja putri telah dilakukan oleh Dwiriani, dkk. (2011). Hasilnya menunjukkan penambahan zat besi dan asam folat dengan vitamin dan mineral laiinya diantaranya dapat memperbaiki status besi. Penelitian Megawati, M. (2016), diperoleh data dari 41 remaja putri di MA Athoriyah, yaitu sebanyak 32 orang (78\%) mengalami anemia. Berdasarkan hasil pemeriksaan didapatkan mayoritas kadar hemoglobin responden rata-rata 9-11 gr/dl, yaitu sebanyak 29 orang (70,7\%). Kejadian anemia ini termasuk ke dalam klasifikasi anemia ringan. Untuk menindaklanjuti 
penelitian sebelumnya, diperlukan penelitian tentang "Pengaruh konsumsi zat besi terhadap kadar hemoglobin remaja putri di MA Athariyah Cikatomas Kabupaten Tasikmalaya pada tahun 2017".

\section{METODOLOGI PENELITIAN}

Penelitian ini menggunakan Quasi Eksperimen (pra-eksperimen) one-group pre-post test desigen. Populasi adalah seluruh remaja putri pada MA Athoriyah Cikatomas kelas XII yaitu sebanyak 73 orang. Besar sampel diperoleh dari hasil hitung, yaitu sebanyak 50 orang, pengambilan sampel secara total sampling.

Instrumen penelitian ini menggunakan lembar observasi berupa kartu kendali dan alat pemeriksaan kadar hemoglobin yaitu Hemoglobinometer. Analisis data menggunakan analisis univariat, sedangkan untuk menguji hipotesa, yaitu uji t dependen. Proses analisis data dibantu dengan menggunakan program komputerisasi. Hasil analisis data yang diperoleh, yaitu suatu hipotesa (Ho) ditolak apabila nilai $\alpha<\mathrm{p}$ value, yaitu derajat kesalahan yang bernilai 0,05 (Sugiyono, 2007).

\section{HASIL PENELITIAN}

Tabel 1. Rata-Rata Kadar Hb Responden Menurut Pengukuran Sebelum dan Sesudah Pemberian Tablet $\mathrm{Fe}$

\begin{tabular}{lcccc}
\hline \multicolumn{1}{c}{ Kadar Hb } & Mean & SD & SE & P value \\
\hline $\begin{array}{l}\text { Pengukuran } \\
\text { sebelum }\end{array}$ & 11,76 & 1,78 & 0,25 & 0,000 \\
\cline { 1 - 3 } $\begin{array}{l}\text { Pengukuran } \\
\text { sesudah }\end{array}$ & 12,36 & 1,59 & 0,22 & \\
\hline
\end{tabular}

Rata-rata kadar $\mathrm{Hb}$ pada pengukuran sebelum adalah $11,764 \mathrm{gr} \%$ dengan standar deviasi $1,78 \mathrm{gr} \%$. Pada pengukuran sesudah didapar rata-rata kadar $\mathrm{Hb}$ adalah 12,364 gr\% dengan standar deviasi 1,59 gr\%. Terlihat nilai perbedaan antara pengukuran pertama dan kedua adalah 0,6000 dengan standar deviasi 1,134 . Hasil uji statistik didapatkan nilai 0,000 maka dapat disimpulkan ada perbedaan yang signikan antara kadar $\mathrm{Hb}$ sebelum dan sesudah pemberian tablet Fe.
Hasil analisis bivariat dengan korelasi didapatkan nilai $p$-value untuk variabel pola makan $(p=0,837)$, pola menstruasi $(p=0,569)$, status gizi $(p=0,358)$, dan pengetahuan $(p=0,166)$. Dapat disimpulkan bahwa variabel pengetahuan mempunyai $p$ value $<0,25$ (yaitu $p=0,166$ ), sehingga hanya pengetahuan yang bisa lanjut ke pemodelan

\section{PEMBAHASAN}

Berdasarkan hasil penelitian diperoleh data bahwa dari 50 orang responden, sebelum diberikan tablet Fe mayoritas kadar hemoglobin responden rata-rata $<12 \mathrm{gr} / \mathrm{dl}$, yaitu sebanyak 26 orang (52\%) dan sesudah rata-rata $\geq 12 \mathrm{gr} \%$, yaitu sebanyak 15 orang $(35 \%)$. Hal ini sesuai dengan pernyataan Reksodiputro (1994) bahwa dengan mengkonsumsi tablet tambah darah sebesar 1,4 mg/hari dalam waktu 7-10 hari kadar kenaikan Hemoglobin dapat terjadi. Peningkatan kadar hemoglobin dalam darah menurut Sunita Almatsir (2003: 252) juga bisa terjadi selain dengan suplemen yaitu dengan makan makanan yang kaya akan zat besi, asam folat juga vitamin B dan mengkonsumsi jenis makanan yang mudah menyerap zat besi, misalnya makanan yang banyak mengandung vitamin $\mathrm{C}$ tinggi dan menghindari makanan atau minuman yang menghambat penyerapan zat besi, misalnya kopi serta teh.

Asumsi peneliti dengan mengkonsumsi tablet tambah darah sebesar 1 kali dalam seminggu selama 11 minggu kadar kenaikan Hemoglobin dapat terjadi. Namun terdapat banyak faktor risiko terjadinya anemia pada remaja putri diantaranya, pola menstruasi, pola makan serta pengetahuan yang menjadi penyebab terjadinya anemia pada remaja.

Hasil penelitian pada variabel pola makan diperoleh sebagian besar mempunyai pola makan kurang baik, yaitu sebanyak 27 orang (54\%). Angka kejadian ini dipengaruhi oleh perilaku pola makan remaja putri, yaitu meliputi frekuensi makan < 3 kali/hari, keanekaragaman makanan meliputi kurang konsumsi makanan hewani 
$<3$ kali/hari, konsumsi nabati $<2$ kali/hari, konsumsi sayuran dan buah-buahan $<2$ kali/hari, serta jenis minuman yang dikonsumsi yaitu minum kopi $>3$ cangkir dalam seminggu.

Penyebab rendahnya kadar hemoglobin dalam darah salah satunya adalah asupan yang tidak mencukupi kebutuhan gizi remaja. Asupan zat gizi sehari-hari sangat dipengaruhi oleh kebiasaan makan. Pola makan memberikan gambaran mengenai frekuensi, macam dan minuman yang membantu penyerapan yang dilakukan remaja putri di MA Athoriyah tidak sesuai dengan standar menu gizi seimbang.

Sejalan dengan hasil penelitian Megawati, M., (2016) pada variabel status gizi diperoleh sebagian besar responden memiliki status gizi yang normal, yaitu sebanyak 28 orang (56\%). Jumlah ini menandakan bahwa status gizi pada remaja putri di MAN At-Thoriyah bukan merupakan masalah karena dibandingkan dari 41 orang siswa sebagian besar status gizinya normal. Angka kejadian ini dipengaruhi oleh Indeks Masa Tubuh (IMT) pada remaja putri sebagian besar berada pada ambang batas normal yang ditentukan oleh Kemenkes (2011), yaitu -2 SD sampai dengan 1 SD.

Hasil penelitian pada variabel pola menstruasi diperoleh sebagian besar mempunyai pola menstruasi yang beresiko anemia, yaitu 42 orang (84\%). Angka kejadian ini menjelaskan tentang lamanya menstruasi remaja putri yang masih dianggap normal, yaitu selama $\leq 7$ hari dan kehilangan zat besi $\pm 1,3 \mathrm{mg}$ per harinya.

Salah satu penyebab anemia gizi pada remaja putri adalah kehilangan darah secara kronis melalui kehilangan darah yang terjadi secara alamiah setiap bulan melalui menstruasi. Jika darah yang keluar selama menstruasi sangat banyak maka akan terjadi anemia defisiensi besi (Arisman, 2004).

Berdasarkan hasil penelitian diperoleh rata-rata kadar $\mathrm{Hb}$ pada pengukuran sebelum adalah 11,764 gr \% dengan standar deviasi 1,78 gr\%. Pada pengukuran sesudah didapat rata-rata kadar $\mathrm{Hb}$ adalah
12,364 gr\% dengan standar deviasi 1,59 gr\%. Terlihat nilai perbedaan antara pengukuran pertama dan kedua adalah 0,6000 dengan standar deviasi 1,134 . Hasil uji statistik didapatkan nilai 0,000 maka dapat disimpulkan ada perbedaan yang signikan antara kadar $\mathrm{Hb}$ sebelum dan sesudah pemberian tablet Fe.

Hasil dari analisis bivariat dengan korelasi didapatkan nilai $p$ value untuk variabel pola makan $(p=0,837)$, pola menstruasi $(p=0,569)$, status gizi $(p=0,358)$, dan pengetahuan $(p=0,166)$. Dapat disimpulkan bahwa variabel pengetahuan mempunyai $p$ value $<0,25$ (yaitu $p=0,166$ ), sehingga hanya pengetahuan yang bisa lanjut ke pemodelan.

Anemia merupakan masalah gizi yang paling umum di seluruh dunia, terutama disebabkan defisiensi besi. Kekurangan zat besi tidak terbatas pada remaja status sosial ekonomi pedesaan yang rendah tetapi menunjukkan peningkatan prevalensi di masyarakat yang makmur dan berkembang. Prevalensi anemia remaja $27 \%$ di negaranegara berkembang dan $6 \%$ di negara maju. Menurut $\mathrm{WHO}$, apabila prevalensi anemia $>40 \%$ termasuk kategori berat (Suryani, dkk., 2015).

Dampak anemia bagi remaja putri, yaitu menurunnya kesehatan reproduksi, terhambatnya perkembangan motorik, mental dan kecerdasan, menurunkan kemampuan dan konsentrasi belajar, mengganggu pertumbuhan sehingga tinggi badan tidak mencapai optimal, menurunkan fisik olahraga serta tingkat kebugaran, serta mengakibatkan muka pucat.

Terdapat banyak faktor risiko terjadinya anemia pada remaja putri diantaranya, pola menstruasi, pola makan serta pengetahuan tentang anemia. Hal tersebut termasuk dalam masalah kesehatan masyarakat. Sehingga diperlukan lebih seperti: melakukan penyuluhan, pemeriksaan $\mathrm{Hb}$ rutin pada sekolah-sekolah, serta pemberian tablet tambah darah (TTD)/tablet Fe. 


\section{KESIMPULAN}

Sebelum diberikan tablet $\mathrm{Fe}$, sebagian besar responden mengalami anemia, yaitu sebanyak 26 orang (52\%). Sesudah diberikan tablet $\mathrm{Fe}$, sebagian besar responden tidak mengalami anemia, yaitu sebanyak 35 orang (65\%). Terdapat perbedaan yang signifikan antara kadar $\mathrm{Hb}$ sebelum dan sesudah pemberian tablet $\mathrm{Fe}$, dapat disimpulkan ada pengaruh konsumsi tablet $\mathrm{Fe}$ terhadap kenaikan kadar hemoglobin $(p=0,000)$.

Diharapkan remaja putri memperbaiki perilaku hidup sehat, diantaranya: merubah pola makan yang sehat dan berkualitas, mencegah anemia pada saat terjadi menstruasi dengan mengkonsumsi tablet tambah darah, dan mencari informasi terkait penanggulangan anemia untuk mempersiapkan kesehatan reproduksinya menjelang pernikahan dan proses kehamilan.

Sedangkan bagi sekolah MA AtThariyah dapat lebih intensif memberikan pendidikan kesehatan/penyuluhan tentang anemia kepada remaja putri, serta rutin memberikan tablet Fe 1 kali/minggu dan 1 tablet selama 10 hari pada saat menstruasi, serta melakukan pemeriksaan kadar hemoglobin setiap 3 bulan sekali, bekerjasama dengan tenaga kesehatan atau instansi pelayanan kesehatan setempat.

\section{DAFTAR PUSTAKA}

Almatsier, S., (2001). Prinsip Dasar IImu Gizi, Penerbit PT. Gramedia Pustaka Utama, Jakarta.

Arikunto, S., (2006). Prosedur Penelitian Suatu Pendekatan Praktek, Penerbit Rineka Cipta, Jakarta.

Arisman, (2004). Gizi dalam Daur Kehidupan, Penerbit Buku Kedokteran EGC, Jakarta.

Arumsari, E., (2008). Faktor Risiko Anemia pada Remaja Putri Peserta Program Pencegahan dan Penanggulanagn
Anemia Gizi Besi (PPAGB) Di Kota

Bekasi, Skripsi Fakultas Pertanian

Institut Pertanian Bogor, Bogor.

Anonymaous, (2013) Perdarahan Berlebih

Saat Menstruasi. Dalam situs

URL:http://Wanita-Dunia-

Wanita/Perdarahan/Berlebih/Saat/Mens

truasi. Diakses 5 Mei 2016.

Husaini, dkk., (1989). Nutritional Anemia An

Assesment of Information Compilation

for Supporting and Formulating

National Policy and Program, Direktorat

Bina Gizi Masyarakat dan Pusat

Penelitian dan Pengembangan Gizi,

Depkes RI, Jakarta.

Kemenkes RI., (2.014). Peraturan Menteri Kesehatan Republik Indonesia Nomor 41 Tahun 2014 Tentang Pedoman Gizi Seimbang, Kementerian Kesehatan Republik Indonesia, Jakarta.

Megawati, M., (2016). Faktor-faktor yang mempengaruhi kejadian anemia di MA Athariyah Cikatomas Kabupaten Tasikmalaya pada tahun 2016.Jurnal Kesehatan Bakti Tunas Husada, Volume 16 Nomor 1 Agustus 2016, ISSN: 1979-004X

Notoatmodjo, S., (2005). Metodologi Penelitian Kesehatan, Penerbit Rineka Cipta, Jakarta.

Permaesih, dkk. (2005). Faktor-faktor Yang Mempengaruhi Anemia pada Remaja, Buletin Penelitian Kesehatan, Volume 33, No.4, 2005:162-171, Jakarta.

Suryani, Hafiani dan Junita (2016). Analisis Pola MAkan dan Anemia Gizi Besi pada Remaja Putri Kota Bengkulu, Jurnal Kesehatan Masyarakat Andalas, Volume 10, No.1, 2016: 11-18, Bengkulu.

WHO., (2001). Iron deficiency, anemia, prevention, and control, A guide for programme managers, WHO, Geneva. , (2008). Wolrdwide Prevalence of Anemia 1993-2005, WHO Global Database on Anaemia, WHO, Geneva. 